This is an electronic reprint of the original article. This reprint may differ from the original in pagination and typographic detail.

Author(s): Napolitano, Maria Rosaria; Marino, Vittoria; Ojala, Jari

Title: In search of an integrated framework of business longevity

Year: $\quad 2015$

Version:

Please cite the original version:

Napolitano, M. R., Marino, V., \& Ojala, J. (2015). In search of an integrated framework of business longevity. Business History, 57(7), 955-969.

https://doi.org/10.1080/00076791.2014.993613

All material supplied via JYX is protected by copyright and other intellectual property rights, and duplication or sale of all or part of any of the repository collections is not permitted, except that material may be duplicated by you for your research use or educational purposes in electronic or print form. You must obtain permission for any other use. Electronic or print copies may not be offered, whether for sale or otherwise to anyone who is not an authorised user. 


\section{In search of an integrated framework of business longevity}

Maria Rosaria Napolitano, Vittoria Marino, Jari Ojala

Why some companies survive while others fail is a fundamental puzzle for both business history and management research. Earlier research has pointed out a number of factors that might explain survival, such as branch of industry, size of company, stage of maturity, privileges, transformation capability, cultural context, historical time, and pure good luck. Nevertheless, there is no single explanation for longevity, or even consensus on why companies should survive in the first place, as the aim for long-term survival might jeopardize (short term) profitability. ${ }^{1}$

While business historians tend to see survival as a performance measure for a firm ${ }^{2}$, in management studies performance and survival are rather separated ${ }^{3}$. For economic theory, however, business longevity is a rather complicated issue, as in the face of the classic equilibrium model no company should prevail over others in market competition without some extraordinary rights (provided e.g. by the state), extraordinary capabilities (e.g. in technology), or capability to continually develop new processes and routines to meet the competition. ${ }^{4}$ Yet even some mainstream organizational theory is, at least implicitly, based on the assumption that the firm is at theoretical level an everlasting entity which is, or at least should be, permanent, and as such motivated by a need to survive over time. ${ }^{5}$ This, however, does not necessarily lead to business longevity as organizations and organizational forms constantly complete for the survival "of fittest". 6 From the history of business we know that firms are seldom "built to last", but more often bound to lose. ${ }^{7}$

Business longevity is also a relative term: how old should a company be before it is classified as a "survivor"? In a continuously changing scenario that makes business survival a daily challenge, it seems appropriate to ask whether or not a firm having been in operation for at least five or ten years can be considered long-lived. Furthermore, in most cases it is not even clear what has survived over decades or even centuries in long lasting firms: is it the name of the company, the brand, ownership, or something else? The competencies created within the company might survive even if the company as a legal entity dies out, as knowledge and technology may be transferred to other organizations. Also, in cases where a company is merged with or bought out 
by a competitor, it may continue as a part of a new organization in spite of losing its independence.

Regardless of the possible causes of longevity, all business firms fade out of existence at some point. Most of them die young: only about half of the new-born European companies survived more than five years in the early $2000 \mathrm{~s} .{ }^{8}$ Even the oldest ones may vanish, as happened to the Japanese temple builder Kongo Gumi, celebrated as the oldest continuously operating company in the world that ceased to exist as an independent company in 2006 after 1,428 years of existence. ${ }^{9}$ Leslie Hannah has argued that the "quarter-life" of the world's largest companies during the twentieth century was 33 years; that is the time taken for a quarter of companies to disappear. ${ }^{10}$ The dataset based on Fortune-500 companies for the period 1970 to 1983 suggests that the life expectancy of big companies was between 40 and 50 years. ${ }^{11}$ Of the largest British, French and German companies in 1907, according to Yossef Cassis, the majority had vanished by the end of the $1980 \mathrm{~s}^{12}$

Although most companies die young and some in their middle age, there still is a plethora of companies that have existed not only for decades but for centuries - and have been able to maintain their vitality for decades. In Japan, for example, companies over 100 years old have a society called Shinise ("established and long standing company"). ${ }^{13}$ Les Hénokiens, in turn, is a fraternity, originally established in France, of companies that are at least 200 years old, and the British Tercentenarians Club is for companies at least 300 years old. ${ }^{14}$ These associations and their member companies are, however, exceptional cases.

The typical features for extraordinarily long living companies throughout history are relatively small or medium size and family ownership. ${ }^{15}$ Therefore both management and business history research have concentrated specifically on explaining the survival of family firms that seem to be resilient over time ${ }^{16}$. However, the statistics suggest that on average large and publicly owned firms are more likely to live longer. Stadler, using a large database including over seven million European companies in 2005 calculated that the average age of all companies was 12.3 years, of publicly traded companies 28 years, and of large corporations with more than 10,000 employees 48 years on average. ${ }^{17}$ Leslie Hannah, in turn, has argued that big companies are more likely to survive longer as they have more resources available. According to Hannah, however, locally oriented small-sized companies might have good chances to grow in age if they are not facing 
international (or even national) competition. ${ }^{18}$ There are, however, striking differences in the strategies to maintain longevity among large and small companies. To survive big companies have to grow bigger: Hannah has counted that "to raise a joint-stock company's half-life by one year, it is necessary to increase its size by twenty-three times". ${ }^{19}$ For small firms the sustainable exploitation of local resources and demand, in turn, may be the key to longevity. ${ }^{20}$ As highlighted by de Geus, a paradox is hidden in the extreme gap between the potential survival expectancy and the average effective life of a company. ${ }^{21}$ Such a gap makes firms unique when compared to living species and is exacerbated by the contrasting increase achieved in the last century in the average human lifespan.

The data on business survival entail implications that affect not only the businesses themselves but, more generally, the economic and social system in which companies emerge and die. Numbers of other stakeholders are affected from the survival of the firm: employers, suppliers, customers, and even competitors. Certainly the survival of the company is a key issue for a number of them; the local community in particular may be dependent on the survival of the dominating company in the area. The damaging effect of business failure on communities and individuals was also noted by Joseph Schumpeter, even though he praised the importance of enterprises and entrepreneurs in a capitalistic system. ${ }^{22}$

The testimony offered by the minority of companies able to ride out the centuries represents an additional incentive for scholars to explore the key factors explaining longevity. The vast number of empirical contributions presented in recent decades has approached longevity in business enterprises adopting several perspectives and different measures, dealing with both survival and failure considered as two sides of the same coin. This special issue on business longevity analyses the abovementioned big issues in business history and aims to offer frameworks to conceptualize longevity and representative cases in order to generalize on the subject matter.

\section{Exploring the key factors of business longevity: explanations from management studies and business history}

Even if the domain of business longevity has been enriched by the multidisciplinary nature of approaches used to investigate the phenomenon, the lack of a unifying perspective has impeded 
systematic research and encountered definitional ambiguity along with a difficulty to decide which variables to use in order to assess longevity. In this regard, the relationship between business history and management studies has markedly affected the theoretical development of business longevity research.

Business historians tend to use the survival of a company as one indicator of business success. Unlike many other indicators, such as profitability and productivity, longevity can relatively easily be compared in time and space; namely, between different historical and cultural contexts. However, as Cassis has pointed out, a number of exogenous factors, and even the line of business, location and size are determinants that affect survival. ${ }^{23}$ The relevant amount of research on business longevity provided in the last decades by management scholars, in turn, has focused mainly on identifying critical success factors ${ }^{24}$, varying from industry to industry, including resources and competencies demonstrating a company's superiority over competitors and which as such must be used to build the most significant competitive advantages. ${ }^{25}$

Several contributions on business longevity have emerged in strategy research and organizational theory - both widely also used in business history research. Strategy research emphasizes internal characteristics, management practices and strategic choices seeking to identify the explanatory factors of long-run success drawing on consolidated theoretical foundations from the broader strategic management field. Specifically, the resource-based view of the firm (RBV) represents a relevant theoretical perspective adopted to highlight the role of firm-specific assets in achieving the sustainable competitive advantage necessary to survive over time. ${ }^{26}$ The organization's capabilities ${ }^{27}$ to explore and exploit its internal and external resources are a key to business longevity. According to this stream of research business longevity is constrained by the capabilities of the firm to be sensitive to the changes in its environment. Tolerance to changes is a typical feature of long surviving firms. ${ }^{28}$ A recent analysis of Italian family firms suggests that all companies that have lived extraordinarily long were able to adapt to the changes in the environment. ${ }^{29}$ Conversely, a firm that is perfectly adapted to its environment may lack the ability to change, and therefore fall victim to its own competencies and routines when the environment changes. ${ }^{30}$ Fallibility may even be accentuated if the company repeats a former success receipt that no longer works, as recently shown in a study by Arjan van Rooij. ${ }^{31}$ Thus, path dependence can lead to the company's downfall. 
Empirical investigations of business longevity falling into the province of strategy research have provided evidence for the central role of a core ideology and strong sense of identity ${ }^{32}$ which, combined with sensitivity to the environment and conservative finance, ${ }^{33}$ enable firms to succeed over time on the basis of a long-term vision. In this line of thought, the ability to adapt business strategies and practices to meet the changing environment is a key factor characterizing companies able to survive over time. Other strategic management scholars looking for the recipe for enduring success have highlighted the importance of conservative and cautious behaviors instead $^{34}$, thus giving exploration and change a marginal role in the growth pattern of long-lived firms. Alongside a specific field of expertise, business continuity management, has emerged. ${ }^{35}$

While the strategy literature has mainly focused on explaining long-term success through the identification of key internal factors, in organization theory a significant number of studies have been conducted to assess the effects of external conditions on business survival. The theoretical foundations of such studies are mainly derived from the integration of two main perspectives, namely organizational population ${ }^{36}$ and evolutionary economics ${ }^{37}$, reconciled in order to assess the time-varying effects of organizational variables - like size and age - and environmental characteristics - like density, competition level and industry life cycle - on firms' chances of survival. In close interaction with economics, sociology and business history, these theoretical perspectives have provided empirical support for the impact of evolutionary changes in the competitive context on business mortality rates, as well as on the co-evolutionary relationships between a firm and its environment in organizational survival ${ }^{38}$. The organizational ecology perspective has likewise been introduced to business history when analyzing large samples of companies or branches of industries over an extended period of time. ${ }^{39}$

In a significant number of studies organizational ecology arguments have been put forward to investigate the effects of founding conditions on the survival of new firms. ${ }^{40}$ The focus on new firms also characterizes a growing body of literature investigating the role of spatial differences in explaining organizational survival based on the often-stated positive relationship between entry and exit rates. ${ }^{41}$ The maturity of the industry also has an effect on survival: according to several studies, death rates are higher during the early stages of an industry, while both exits and entries diminish towards maturity. ${ }^{42}$ Due to the high failure rates recorded among new firms, in fact, many empirical efforts have been devoted to identifying conditions promoting their 
survival, while historical studies seeking to explain long-term success over decades or even centuries are to date still rare. ${ }^{43}$ Furthermore, as mentioned above, studies aiming at investigating longevity factors have often yielded contrasting results and attempts at integrating internal and external perspectives have not so far resulted in any systematic definition of key factors enhancing long-term success. In this direction, however, Porter's consolidated approach to competitive environment suggests that the integration of endogenous and exogenous factors is useful to explain firms' long-term competitiveness, as it emphasizes that the competitive value of resources is decisively affected by changes in markets, technology and competitors' behavior. Despite this central contribution and further efforts intended to highlight how endogenous factors are not valuable in and of themselves in ensuring firms' competitiveness and survival, multidisciplinary perspectives able to incorporate into unique theoretical frameworks the internal and external keys of longevity are to a large extent still lacking. ${ }^{44}$

A brake in this direction is probably attributable to the narrow focus of the business longevity literature, originally developed with the main aim of identifying the key factors of long-term success among family firms, representing the oldest and most prevalent type of business organization worldwide. ${ }^{45}$ Business history has likewise paid attention to longevity, especially in the family firm context, quite often emphasizing the social perspective: the longevity of a firm is a component of the prosperity of the family as a whole - and vice versa. ${ }^{46}$ As Colli and Larson recently pointed out, "longevity and survival -- are in family firms' strategic goals and, simultaneously, a relevant measure of performance". ${ }^{47}$ Even the very definition of family firm is derived from business longevity: namely, a company is usually defined as a family firm if it has survived at least one generational change of ownership. ${ }^{48}$ Therefore several points of intersection can be identified between business history and family business studies as regards longevity, since attention in both fields has traditionally addressed the problems related to processes of handover from one generation to the next and the subsequent difficulties of family firms to survive across generations. In this regard, it is estimated that only 30 per cent of family businesses generally survive into the second generation and only less than 15 per cent survive through to the third generation. ${ }^{49}$ Therefore the inability of family firms to survive beyond the third generation has made it essential to investigate the factors which are conducive to survival. 
Much of the literature on family business longevity deals with the question of whether the overlap between the family and the firm may foster or hamper long-term success. In this regard, two main perspectives have emerged in recent years, generally recognized as the stewardship perspective $^{50}$ and the stagnation perspective. The former includes contributions considering the family business as an organizational form fostering corporate longevity due to the strong interconnections between the two entities with the subsequent economic responsibilities and socio-emotional bonds - both also emphasized in business history research. ${ }^{51}$ In this line of thought, significant attention has been paid to the investigation and categorization of unique values rooted in the family and transmitted across generations due to their crucial contribution to the enhancement of a long-term vision within family firms. ${ }^{52}$

In sharp contrast to the above arguments, the stagnation perspective views family business as an obstacle to growth, owing to conservative behaviors and agency problems that do not favor longterm objectives and preservation. ${ }^{53}$ This, at least implicitly, has also been the view in the mainstream business history literature, following Alfred Chandler's argument that only large corporations are able to adopt the complicated marketing and organizational structures required in modern economy, while inherited business creates complacency and conservatism. ${ }^{54}$

Research on business longevity has also focused on the entrepreneur's perspective, with a growing number of studies aimed at investigating the influence of individual traits on business survival. ${ }^{55}$ In the specific field of family business, considerable attention has been paid to the effects of corporate entrepreneurship, that is, entrepreneurial activities within the organization, on long-term survival. ${ }^{56}$ In fact, many points of intersection between family business and the longevity literature can be identified in the field of entrepreneurship, which is also a promising area for interaction between management and business history studies.

In this growing stream of research, several contributions have noted that owing to the aspiration to create value across generations, strategic decisions and actions within family firms are inspired by a long-term orientation that can be source of distinctive advantages for this category of firms. ${ }^{57}$ The unique position of family firms is outlined by several works in the field of entrepreneurship, drawing on the concept of multitemporality in order to explain the ability of these firms to meet both short-term and long-term challenges for ensuring business prosperity and survival. ${ }^{58}$ This ability clearly refers to the parallel concept of ambidexterity, that is, the 
successful balance between exploration and exploitation, which has attracted much scholarly attention in the field of strategic management. ${ }^{59}$ Specifically, a pervasive debate in the current literature on business longevity revolves around the way exploration and exploitation must be

pursued to connect present and future challenges and ensure business continuity. ${ }^{60}$ Nevertheless, less attention has been paid to understanding the effects of external conditions on the effectiveness of ambidexterity approaches. ${ }^{61}$ Therefore, the ability to nurture existing resources in order to ensure current viability must be accompanied by a constant adaptability to the changing external environment, since unexpected challenges and opportunities may be decisive for the future.

As a consequence, both internal and external perspectives must be considered when trying to identify the key factors that enhance survival. As briefly noted, earlier work on business longevity reveals that many empirical and theoretical efforts have been made in both directions by adopting several perspectives, the pursuit of which pursuit has contributed to advancing knowledge of the field. Nevertheless, a considerable gap remains to be bridged, mainly due to both the narrow focus on family business and the necessity of considering external and internal factors influencing business longevity through an integrated perspective able to facilitate dialogue among different disciplines.

Even though we cannot ignore the central role that family business still retains in the development of business longevity, this Special Issue was conceived in order to expand research perspectives on a wider range of enterprises of different sizes, sectors and ownership forms. Thus family firms play only a limited role in the articles presented here. The challenging points of intersection emerging in this multidisciplinary field of study represent in our view the first stage at which to bring together different strands of research in order to enhance our understanding of a phenomenon of crucial importance both economically and socially.

\section{The contents of this Special Issue}

This special issue was conceived with the main aim of enhancing the scientific knowledge of business longevity by integrating theoretical and empirical studies adopting different approaches and perspectives to identify the key factors of long-term success and the effect of longevity on 
firm performance. The multifaceted nature of business longevity research is mirrored in five articles that offer different and interesting perspectives for the investigation of the domain.

Many of the issues arising in this introduction are further analyzed in the opening article by Angelo Riviezzo, Mika Skippari and Antonella Garofano "Who wants to live forever? Exploring 30 years of research on business longevity". The article marks systematic research progress in the field of business longevity and notes that business longevity is of great interest to both business history and management scholars. The authors categorize the existing literature through an analysis of the articles published on the topic in the leading journals of business history and management over the last three decades. On the basis of this bibliometric analysis, the authors highlight the need to integrate different perspectives, explanatory models and research strategies, as well as a need for cross-industry and cross-national studies. Another issue to be addressed in future studies on business longevity, according to them, is the lack of interdisciplinary cooperation among scholars from different fields, specifically management and business history, which could make a crucial contribution to fill the main gaps in the existing literature.

Riviezzo et al. emphasize the key role played by the organizational population ecology literature in laying the theoretical foundations of business longevity. The study following this type of methodology in this special issue is the article by Björn Eriksson and Maria Stanfors ("A Winning Strategy? The employment of women and firm longevity during industrialization"). By using the entire population of the Swedish late nineteenth and early twentieth century tobacco industry as a case, the authors argue that firms which employed more women were considerably less likely than other firms to fail. This, in turn, may be attributable to the competitive advantage that the female labour force gave the companies to generate higher profits.

The article by Cinzia Lorandini ("Postponing the Buddenbrooks Syndrome: The Salvadori Firm of Trento, 1660s-1880s") describes a family firm case of business longevity. The crucial role played by the family is highlighted in the firm's longevity, even though family ownership has also caused challenges. Lorandini's case is the Salvadori Firm of Trento, specializing in retail and wholesale, and lately in the silk trade. Lorandini finds certain interrelated factors for family firm business longevity; namely, the firm's and family's capability to respond to various changes in their environment and the ability to transfer skills, values and family assets from one generation to another. 
The articles by Innan Sasaki ("Cultural Approach to Understanding the Long-Term Survival of Firms - Japanese Shinise Firms in the Sake Brewing Industry”) and Arturo Capasso, Carmen Gallucci and Matteo Rossi ("Standing the test of the time. Does firm performance improve with age? An analysis in the wine industry") both examine types of businesses in which the longevity is a face value and an important part of the brand. While Sasaki concentrates on the sake brewing industry, Capasso et al. are analyzing the wine industry. Thus legitimacy in the markets in these types of businesses derives from tradition, which may in turn lead to longevity. Interestingly, these articles also analyze countries in which business longevity is a fairly typical phenomenon, namely Japan and Italy. While Sasaki concentrates on the exceptionally old sake breweries, Capasso et al. make comparisons between companies that they define as "young" and "old".

Innan Sasaki concentrates on five firms that have more than one hundred years of history in the sake brewing industry in Kyoto. She argues that the major reason for the business longevity in her cases was the capability of the studied firms to combine continuity in their essential rationale and changing cultural interaction with the enhanced local environment. Capasso et al. analyze the effects of longevity on a firm's economic and financial performance. According to the analysis of the economic and financial results respectively achieved by two samples of "old" and “young" Italian wineries over the period from 2008 to 2011, the authors note that the old firms outperform the young ones in terms of revenue growth and financial strength. On the basis of their regression analysis, the authors argue that longevity positively affects revenue growth and financial ratio, but the effect on profitability is negative. Therefore the article sheds light on a less investigated topic in the field of business longevity that concentrated in seeking the key factors of enduring success rather than the effects that long-term survival may exert on firm performance.

\section{Looking ahead through a multi-purpose theoretical lens}

What, then, can business history contribute to the discussion on business longevity? Like all historical research, business history, too, emphasizes context - the time and cultural setting in which the activity, in this case longevity - occurs. While management studies are mostly interested in today's perspective - namely to explain why some companies today have an exceptionally long history behind them - for the business historian longevity in medieval Japan is 
equally important as in post-war Northern Europe. However, as the contexts and cultures are different, so also may be the explanations of longevity. Nevertheless, there seem to be certain "archetype" reasons for longevity, most often rather loosely defined as a company's capability to adjust to changes in its operating environment. All the articles in this special issue confirm this. Explanations for longevity may, in turn, explain another, even more common phenomenon in business life, namely failure. ${ }^{62}$

Building on the above arguments, we suggest that a strong connection has emerged in recent decades between business history and management research, whose integration might be mutually beneficial. ${ }^{63}$ However, distinct research traditions and approaches emerged in the two fields, since business historians - while recently opening to other disciplines - have remained closer to their intellectual origins, thus having few opportunities to build a more robust dialogue with management scholars. Similarly, management scholars tend to be bound with their theoretical discussions which sometimes makes it difficult to clearly see the historical context of the cases studied. Notwithstanding, we do believe that the integration of approaches typical of business historians, namely studies based on in-depth investigations of firms' histories, and approaches adopted in a growing number of management studies is likely to provide many interesting insights for future research on the topic.

In light of these arguments, we believe that there is a clear need for academics in both fields to engage in dialogue about the key factors of business longevity that cannot be systematically assessed without an integrated perspective able to understand the specific contributions of internal resources and external changes to the enhancement of enduring success.

As has clearly emerged from the contributions in this special issue, the complexity of business longevity as a field of study is also determined by the multiple levels of interaction among entrepreneurs, firms, markets and environments that have been proven in different ways to affect the ability of a company to survive over time. These arguments call for an integrated multidisciplinary perspective for analyzing the numerous issues related to business longevity, considering both the environmental approaches for the investigation of external drivers of longterm survival and resource-based approaches for the analysis of internal factors fostering business continuity over time. 
In this regard, many consolidated frameworks available from the wide field of management literature have also been used extensively by business historians and still retain their crucial importance to the understanding of business longevity factors. Specifically, theoretical support for business longevity can be found in the perspective of RBV that in indispensable to the investigation of tangible and intangible internal factors explaining long-run success.

Due to the growing academic awareness of the need to explore new opportunities while exploiting the heritage of long-lived family firms, theoretical support for the investigation of key factors of business longevity can be offered by the perspective of dynamic capabilities, defined as organizational and strategic routines by which firms achieve new resource configurations, thus adapting to a continuously changing environment. ${ }^{64}$ In other words, the dynamic capabilities view reflects a groundbreaking perspective that appears particularly suitable as a theoretical background to business longevity, due to the often-stated necessity to adapt strategic choices to external evolution in order to preserve both current and future viability.

Theoretical support for the external perspective can be found in the heritage of evolutionary economics and population ecology which, as noted earlier, have been widely used by both management scholars and business historians as explanatory models of business longevity. Furthermore, the heterogeneity of the variables used to assess longevity draws the attention to the problem of whether the mere survival over certain time limits can always be considered a measure of success.

In other words, is longevity in any case a desirable objective for the firm? A negative answer to this question was given by John Kay who, in a recent article published in the Financial Times, stated that "sometimes the best that a company can hope for is death", thus totally rejecting the idea that there is always a future for a company - if management makes the right decisions, as expressed by Theodore Levitt around fifty years before. ${ }^{65}$

In this regard, future research efforts should be directed at a better understanding of what it really means to be successful over long periods of time, considering the multiple perspectives of all categories of subjects that directly or indirectly influence or, in turn, are influenced by the events occurring in the firm. 
Being successful over time means meeting present and future challenges by exploiting the heritage of the past while continuously exploring new opportunities. The sustainable growth of the firm, based on the integration of all the interests expressed by its stakeholders and aimed at creating value for all of them ${ }^{66}$, is actually an essential precondition for enhancing its long-term survival probabilities.

\section{BIBLIOGRAPHY}

Agarwal, Rajshree and Michael Gort. "The Evolution of Markets and Entry, Exit and Survival of Firms." The Review of Economics and Statistics 78, no. 3, (1996): 489-498.

Agarwal, Rajshree, M.B. Sarkar, and Raj Echambadi. "The conditioning effect of time on firm survival: An industry life cycle approach." Academy of Management Journal 45 no. 5, (2002): 971-994.

Alchian, Armen A. "Uncertainty, Evolution, and Economic Theory." Journal of Political Economy, 58, no. 3 (1950): 211-221.

Allio, Michael K. "Family businesses: their virtues, vices, and strategic path." Strategy \& Leadership 32, no. 4: (2004): 24-33

Baptista, Rui and Murat Karaöz. "Turbulence in Growing and Declining Industries." Small Business Economics 36, no.3 (2011): 249-70

Baldwin, John R. and Paul .K. Gorecki. "Firm Entry and Exit in the Canadian Manufacturing Sector, 1970-1982." The Canadian Journal of Economics 26, no. 2, (1991): 300-323

Barney, Jay B. "Firm Resources and Sustained Competitive Advantage." Journal of Management 17, no. 1 (1991): 99-120

Brixy, Udo, and Reinhold Grotz. "Regional patterns and determinants of birth and survival of new firms in Western Germany." Entrepreneurship and Regional Development 19, no. 4 (2007): 293-312.

Burgelman, Robert A., and Andrew S. Grove. "Let chaos reign, then rein in chaos - repeatedly: Managing strategic dynamics for corporate longevity." Strategic management journal 28, no.10 (2007): 965-979.

Cassis, Yossef. Big Business. The European Experience in the Twentieth Century. Oxford: Oxford University Press, 1997.

Casson, Mark. "Entrepreneurship and Business Culture". In: Jonathan Brown and Mary Rose, Entrepreneurship, Networks and Modern Business. Manchester: Manchester University Press 1993, 30 - 54.

Casson, Mark. "The Economics of the Family Firm." Scandinavian Economic History Review 47, no 1 (1999): $10-23$.

Chandler, Alfred D. Jr. Scale and Scope. The Dynamics of Industrial Capitalism. Cambridge, Mass.: The Belknap Press of Harvard University Press, 1990.

Chrisman, James J., Jess H. Chua, and Reginald A. Litz. "Comparing the Agency Costs of Family and Non-Family Firms: Conceptual Issues and Exploratory Evidence." Entrepreneurship Theory and Practice, 28 no. 4 (2004): 335-354.

Chua, Jess H.; James J. Chrisman and Pramodita Sharma. "Defining the Family Business by Behavior." Entrepreneurship Theory and Practice 23, no. 4 (1999): 19-39.

Church, Roy. "The Family Firm in Industrial Capitalism: International Perspectives on Hypotheses and History." Business History 35, no. 4, (1993): 17-43.

Clark, Peter and Michael Rowlinson. "The Treatment of History in Organisation Studies: Towards an "Historic Turn?".” Business History 46 no. 3 (2004): 331 - 352.

Colli, Andrea The History of Family Business, 1850 - 2000. Cambridge: Cambridge University Press, 2006. 
Colli, Andrea "Contextualizing Performances of Family Firms: The Perspective of Business History." Family Business Review 25 (2012): 243- 257.

Colli, Andrea, Martin J. Iversen, and Abe de Jong. "Mapping strategy, structure, ownership and performance in European corporations", in Andrea Colli, Abe de Jong, and Martin Jes Iversen (eds.) Mapping European Corporations: Strategy, Structure, Ownership and Performance. Routledge, Abingdon 2013, 1-13.

Colli, Andrea; Carole Howorth and Mary Rose. "Long-Term Perspectives on Family Business." Business History 55, no. 6 (2013): 841 - 854.

Colli, Andrea and Mats Larsson. "Family business and business history: An example of comparative research". Business History 56, no. 1 (2014): 37 - 53.

Collins, James Charles, Jerry I. Porras, Built to last: Successful habits of visionary companies. New York: HarperCollins Publishers, 1994.

Conner, Kathleen R. "A Historical Comparison of Resource-Based View and Five Schools of Thought within Industrial Organization Economics: Do We Have a New Theory of the Firm?" Journal of Management 17, no. 1 (1991): 121-154.

Corbetta, Guido, and Carlo Salvato. "Self-Serving or Self-Actualizing? Models of Man and Agency Costs in Different Types of Family Firms: A Commentary on "Comparing the Agency Costs of Family and Non-family Firms: Conceptual Issues and Exploratory Evidence"." Entrepreneurship Theory and Practice 28, no. 4 (2004): 355-362

de Geus, Arie The Living Company: Habits for Survival in a Turbulent Business World. Boston, 1997. Donaldson Lex, and James H. Davis. "Stewardship theory or agency theory: CEO governance and shareholder returns." Australian Journal of Management 16, no. 1 (1991): 49-64.

Drucker, Peter . Adventures of a Bystander, Harper and Row, New York, 1978.

The Economist. "The business of survival. What is the secret of corporate longevity?" December $16^{\text {th }}$ 2004.

Eddleston, Kimberly A., James J. Chrisman, Lloyd P. Steier, \& Jess H. Chua. "Governance and trust in family firms: An introduction." Entrepreneurship Theory and Practice, 34 no. 6 (2010): 1043-1056.

Fama, Eugene F. and Michael C. Jensen. "Agency Problems and Residual Claims." Journal of Law and Economics 26, no. 2 (1983): 327-49.

Fernández Pérez, Paloma and Andrea Colli (eds.). The Endurance of Family Businesses: A Global Overview. Cambridge University Press, 2013.

Freeman R. Edward, Andrew C. Wicks, and Bidhan Parmar, "Stakeholder Theory and 'The Corporate Objective Revisited", Organization Science 15, no 3 (2004): 364-369.

Fridenson, Patrick. "Business Failure and the Agenda of Business History". Enterprise \& Society, 5, no. 4 (2004): 562-582.

Geroski, Paul A., José Mata, and Pedro Portugal. "Founding conditions and the survival of new firms." Strategic Management Journal 31, no. 5 (2010): 510-529.

Gómez-Mejía, Luis R., Katalin Takács Haynes, Manuel Núñez-Nickel, Kathyrn J.L. Jacobson, \& José Moyano-Fuentes. "Socioemotional wealth and business risks in family-controlled firms: Evidence from Spanish olive oil mills." Administrative science quarterly 52, no. 1 (2007): 106-137.

Hannah, Leslie. "Marshall's "Trees" and the Global "Forest": Were "Giant Redwoods" Different?" In N. R. Lamoreaux, D. M. G. Raff \& P. Temin (Eds.), Learning by Doing in Markets, Firms, and Countries. Chicago: University of Chicago Press 1999.

Hannan, Michael T., and John Freeman. "The population ecology of organizations." American journal of sociology 82, no. 5 (1977): 929-964.

Hannan, Michael T., and John Freeman. "Structural inertia and organizational change." American sociological review 49, no. 2 (1984): 149-164. 
Herbane, Brahim. "The evolution of business continuity management: A historical review of practices and drivers". Business History 34, no.6 (2010): 978-1002

Hofer, Charles, Gabriella Mauriello, and Dan Schendel, La formulazione della strategia aziendale, Franco Angeli, Milano, 1984.

Hogarth, Robin, Claude Michaud, Yves Doz, \& Ludo van der Heyden. Longevity of business firms: A four-stage framework for analysis. Fontainebleau: INSEAD, 1991.

Hutcheson, James Olan, "The End of a 1,400-Year-Old Business". Bloomberg Businessweek, April 16, 2007.

Ibrahim, Mohammed, and Pieter M. Ribbers. "The impacts of competence-trust and openness-trust on interorganizational systems.” European Journal of Information Systems, 18, no. 3 (2009): 223234.

Iwasaki, Naoto, and Makoto Kanda. "Sustainability of the Japanese Old Established Companies." Economic Institute of Seijo University 132 (1996): 160-130.

Järvinen, Joonas, Juha-Antti Lamberg, Johan-Peter Murmann, and Jari Ojala, “Alternative Paths to Competitive Advantage: A Fuzzy-Set Analysis of the Origins of Large Firms". Industry \& Innovation 16, no. 6 (2009): 545-574.

Kay, John. "Sometimes the best that a company can hope for is death". Financial Times, August 20, 2013.

Kellermanns, Franz W., and Kimberly A. Eddleston, "Corporate entrepreneurship in family firms: A

family perspective." Entrepreneurship Theory and Practice, 30, no. 6 (2006): 809-830.

Kieser, Alfred. "Why Organisation Theory Needs Historical Analysis and How This Should Be

Performed." Organization Science, 5 (1994): 608-620

Kipping, Matthias, and Behlül Üsdiken, "Business History and Management Studies.” In G. Jones and J.

Zeitlin (eds.) The Oxford Handbook of Business History. Oxford: Oxford University Press, 2008, 96119

Klepper, Steven. "Industry Life Cycles." Industrial and Corporate Change 6, no. 1 (1997): 145-181

Klepper, Steven. "Firm Survival and the Evolution of Oligopoly." RAND Journal of Economics, 33, no. 1 (2002): 37 - 61.

Klepper, Steven and John H. Miller. "Entry, Exit, and Shakeouts in the United States in New Manufactured Products." International Journal of Industrial Organization 13, no. 4 (1995): $567-$ 91.

Kreiser, Patrick M., Jari Ojala, Juha-Antti Lamberg, and Anders Melander, “A historical investigation of the strategic process within family firms". Journal of Management History, 12, no. 1 (2006): 100 $-114$.

Lamberg, Juha-Antti, Jari Ojala, Mirva Peltoniemi and Timo Särkkä (eds.), The Evolution of the?Global Paper Industry 1800-2050: A Comparative Analysis. Dordrecht: Springer, 2012.

Lamberg, Juha-Antti, Juha Näsi, Jari Ojala, and Pasi Sajasalo (eds.), The Evolution of Competitive Strategies in Global Forestry Industries: Comparative Perspectives. Dordrecht: Springer, 2006.

Le Breton-Miller, Isabelle Le, and Danny Miller. "Why Do Some Family Businesses Out-Compete? Governance, Long-Term Orientations, and Sustainable Capability." Entrepreneurship Theory and Practice 30 no. 6 (2006): 731-746.

Levitt, Theodore. "Marketing myopia." Harvard Business Review 38, no. 4 (1960): 24-47.

Levitt, Barbara and James G. March. "Organizational Learning.” Annual Review of Sociology 14 (1988): $319-40$

Lockett, Andy, and Andrew Wild. "Bringing history (back) into the resource-based view". Business

History 56, no 3 (2014): 372-390.

Lumpkin, G. Tom, and Keith H. Brigham "Long-Term Orientation and Intertemporal Choice in Family

Firms." Entrepreneurship Theory and Practice, 35, no. 6 (2011): 1149-1169.

Makadok, Richard. "Toward a Synthesis of the Resource-Based View and Dynamic-Capability Views of Rent Creation.” Strategic Management Journal 22, no. 5 (2001): 387-401. 
March, James G. "Exploration and Exploitation in Organizational Learning." Organization Science, 2, no. 1 (1991): 71-87

Mata, Jose, and Pedro Portugal, "Life duration of new firms." The Journal of Industrial Economics 42, no. 3 (1994): 227-245McCraw, Thomas K.: Prophet of innovation. Joseph Schumpeter and creative destruction, Cambridge (Mass.): Harvard University Press 2009

Miller, Danny, and Isabelle Le Breton-Miller, Managing for the long run: Lessons in competitive advantage from great family businesses. Harvard Business Press, 2005.

Murmann, Johann Peter Knowledge and Competitive Advantage: The Coevolution of Firms, Technology, and National Institutions. Cambridge (Mass.): Cambridge University Press, 2003.

Napolitano, Maria Rosaria., Vittoria Marino,, Angelo Riviezzo, \& Antonella Garofano . Moving forward or running to stand still? The relationship between family firms' strategic posture and longevity". Paper presented at the Aidea bicentary conference, Lecce, 2013.

Nelson, Richard R., and Sidney G. Winter. An Evolutionary Theory of Economic Change. Cambridge, Mass.: Harvard University Press, 1982.

Nicholas, Tom. "Clogs to Clogs in Three Generations? Explaining Entrepreneurial Performance in Britain since 1850." The Journal of Economic History 59, no. 3 (1999): 688-713.

Nordqvist, Mattias. "Familiness in top management teams: Commentary on Ensley and Pearson's "an exploratory comparison of the behavioral dynamics of top management teams in family and nonfamily new ventures: Cohesion, conflict, potency, and consensus"." Entrepreneurship Theory and Practice, 29, no. 3 (2005): 285-292.

Ojala, Jari, Juha-Antti Lamberg, and Anders Melander, "Competitive behaviour and business innovations in the forest industry: Family firms and listed firms in comparison.” In: Paloma Fernández Pérez and Mary B. Rose (eds.), Innovation and Networks in Entrepreneurship in Europe. New York: Routledge, 2009: 118 - 137.

Ojala, Jari, Miikka Voutilainen, and Juha-Antti Lamberg, "The Evolution of the Global Paper Industry: Concluding Remarks". In Juha-Antti Lamberg, Jari Ojala, Mirva Peltoniemi, and Timo Särkkä (eds.) The Evolution of Global Paper Industry 1800-2050; A Comparative Analysis. Dordrecht: Springer, 2012: 345-363

O'Reilly III, Charles A., \& Michael L. Tushman. “Ambidexterity as a dynamic capability: Resolving the innovator's dilemma". Research in Organizational Behavior, 28 (2008): 185-206

Owens, Alastair. "Inheritance and the Life-Cycle of Family Firms in the Early Industrial Revolution." Business History, 44, no. 1 (2001): 21-46

Penrose, Edith T. The Theory of the Growth of the Firm. New York: John Wiley, 1959.

Pfeffer, Jeffrey, \& Gerald R. Salancik. The External Control of Organizations: a Resource Dependence perspective. New York: Harper \& Row, Publishers, 1978.

Porter, Michael. Competitive Advantage. Creating and Sustaining Superior Performance. New York: Free Press, 1985.

Rose, Mary B. "Beyond Buddenbrooks: The Family Firm and the Management of Succession in Nineteenth-Century Britain.” In J. Brown and M. B. Rose (eds.) Entrepreneurship, Networks and Modern Business. Manchester and New York: Manchester University Press, 1993: 127-143

Rowlinson, Michael. "Business History and Organisation Theory." Journal of Industrial History, 4 (2001): 1-23.

Schrör, Hartmut. Business Demography: employment and survival. Eurostat: Eurostat, 2009.

Stadler, Christian. "The four principles of enduring success", Harvard Business Review, 85 no. 7/8 (2007): 62.

Stadler, Christian. Enduring success: what we can learn from the history of outstanding corporations. Stanford University Press, 2011.

Stamm, Isabell, and Christina Lubinski. "Crossroads of family business research and firm demographyA critical assessment of family business survival rates." Journal of Family Business Strategy 2, no. 3 (2011): 117-127 
Swaminathan, Bhaskaran. "Time-varying expected small firm returns and closed-end fund discounts." Review of Financial Studies 9, no. 3 (1996): 845-887.

Teece David J., Gary Pisano, \& Amy Shuen. "Dynamic Capabilities and Strategic Management." Strategic Management Journal, 18, no. 7 (1997): 509-533.

Teece, David J. Dynamic Capabilities and Strategic Management. Oxford: Oxford University Press, 2009.

Tenold, Stig, Martin Jes Iversen, and Even Lange (eds.). Global Shipping in Small Nations. Basingtoke: Palgrave Macmillan, 2012.

Van Praag, C. Mirjam. "Business survival and success of young small business owners". Small Business Economics 21, no. 1 (2003): 1-17.

Van Rooij. "Sisyphus in business: Success, failure and the different type of failure ." Business History (2014): (online/preview)

Wernerfelt, Birger. "A resource-based view of the firm." Strategic management journal 5, no. 2 (1984): 171-180

Üsdiken, Behlül and Alfred Kieser. "Introduction: History in Organisation Studies." Business History 46, no. 3 (2004): 321-330.

Zahra, Shaker A. "Entrepreneurial risk taking in family firms." Family Business Review 18, no.1 (2005): $23-40$.

\footnotetext{
${ }^{1}$ Hogarth \& al. , Longevity, 18.

${ }^{2}$ For example Chandler, Scale and Scope, p. 594; Cassis, Big Business, p. 103; Colli \& al., "Mapping strategy", p. 4; Fridenson, "Business Failure", 565.

${ }^{3}$ Stadler, Enduring, 12.

${ }^{4}$ Hogarth \& al., Longevity, 1-2.

${ }^{5}$ Drucker, Adventures.

${ }^{6}$ Fama \& Jensen, "Agency", 345; Alchian, "Uncertainty", 211-221.

${ }^{7}$ Fridenson, "Business Failure", 563.

${ }^{8}$ Schrör, Business Demography, 4.

${ }^{9}$ Hutcheson, "The End".

${ }^{10}$ Hannah, "Marshall's "Trees"'”, 260.

${ }^{11}$ de Geus, Living Company, 1.

${ }^{12}$ Cassis, Big Business, 104.

${ }^{13}$ Iwasaki and Kanda,"Sustainability", p. 2 (159).

${ }^{14}$ Stadler, Enduring, 7-9; Economist, "Business survival".

${ }^{15}$ Owens, "Inheritance", 22; Fernández Perez \& Colli, Endurance, passim.

${ }^{16}$ See especially Colli \& al., "Long-Term s", 841-854; Church, "Family Firm", 17-43; Miller \& Breton-Miller, Managing, passim.

${ }^{17}$ Stadler, Enduring, 3-5.

${ }^{18}$ Hannah, "'Marshall's "Trees"”, 261, 274; Stadler, Enduring, 5.

${ }^{19}$ Hannah, "Marshall's "Trees"', 261.

${ }^{20}$ Napolitano \& al., "Moving forward", 16-18.

${ }^{21}$ de Geus, Living Company, 1.

${ }^{22}$ McCraw, Prophet, 6.

${ }^{23}$ Cassis, Big Business, 103.

${ }^{24}$ Hofer \& Schendel, La formulazione, passim.

${ }^{25}$ Four books are especially fruitful from this respect, all also targeted at a general audience, namely: Stadler, Enduring; Collin \& Porras, Built to Last; Miller \& Breton-Miller, Managing, passim; and de Geus, Living Company.

${ }^{26}$ Wernerfelt, "Resource-based view", 171-180; Barney, "Firm resources", 99-120; Conner, "Historical Comparison", 121-154; Penrose, Theory of the Growth , passim; Locket \& Wild, "Bringing history", 372-390.

${ }^{27}$ On dynamic capabilities see especially: Makadok, "Toward", 387-401; Teece, Dynamic Capabilities, passim; Teece \& al., "Dynamic", 509-533.

${ }^{28}$ March, "Exploration and Exploitation", 71 - 87; O’Reilly \& Tushman, "Ambidexterity", 185 - 206; Hogarth \& al, Longevity, passim.
} 
${ }^{29}$ Napolitano et al., "Moving forward", 21-22.

${ }^{30}$ Levitt \& March, "Organizational Learning", 319-340; Hogarth \& al., Longevity , 25.

${ }^{31}$ van Rooij, "Sisyphus", 15.

${ }^{32}$ Collins \& Porras, Built to last, passim.

${ }^{33}$ de Geus, Living Company, 7, 176.

${ }^{34}$ Stadler, "Four principles", 62.

${ }^{35}$ Herbane, "Evolution", 978-1002

${ }^{36}$ Hannan \& Freeman, "Population ecology”, 929-964; Hannan \& Freeman, "Structural inertia”, 149-164.

${ }^{37}$ Nelson \& Winter, Evolutionary Theory, passim.

${ }^{38}$ Agarwal \& Sarkar, "Conditioning effect”, 971-994; Murmann, Knowledge, passim; Klepper, "Firm Survival”, $37-$ 61.

${ }^{39}$ For example: Tenold \& al., Global shipping, passim; Järvinen \& al, "Alternative Paths", 545-574; Lamberg \& al., Evolution of Global Paper Industry, passim; Lamberg \& al., Evolution of Competitive Strategies, passim.

${ }^{40}$ Mata \& Portugal, "Life duration", 227-245; Swaminathan, "Time-varying", 845-887; Geroski\& al., "Founding conditions", 510-529

${ }^{41}$ Brixy \& Grotz, "Regional patterns", 293-312; Ojala \& al., "Evolution", 345-363.

${ }^{42}$ Agarwal \& Gort, "Evolution of Markets", 489-498; Baldwin \& Gorecki, "Firm Entry “,300-323; Klepper \& Miller, "Entry,", 567-591; Klepper, "Industry Life Cycles”, 145-181; Baptista \& Karaöz, "Turbulence in Growing”, 249-270

${ }^{43}$ See however Ojala \& al, "Evolution”, 349-352.

${ }^{44}$ See especially Porter, Competitive Advantage, passim.

${ }^{45}$ Ibrahim \& Ribbers, "Impacts", 223-234; Fernández Perez \& Colli, Endurance, passim.

${ }^{46}$ Owens, "Inheritance", 41; Stamm \& Lubinski, "Crossroads", 117-127; Casson "The Economics", 10-23; Rose, "Beyond Buddenbrooks", 127-143 - Overview on recent business history research on family firms in Colli \& al., "Long-Term", 841-854.

${ }^{47}$ Colli \& Larsson, "Family Business", 41 - also Colli, "Contextualizing Performances", 243-257.

${ }^{48}$ Chua \& al., "Defining", 25; Kreiser \& al, "Historical", 101.

${ }^{49}$ Stamm \& Lubinski, "Crossroads", 117-127; Rose, "Beyond Buddenbrooks", 128-129.

${ }^{50}$ Donaldson \& Davis, "Stewardship theory", 49-64.

${ }^{51}$ Corbetta \& Salvato, "Self-Serving", 355-362; Miller \& Breton-Miller, Managing, passim; Nordqvist, "Familiness", 285-292; Gómez-Mejía \& al, "Socioemotional", 106-137; Colli, History, passim.

${ }^{52}$ Colli \& al. "Long-Term", 844.

${ }^{53}$ Allio, "Family", 24-33; Chrisman \& al., "Comparing", 335-354; Zahra, "Entrepreneurial", 23-40.

${ }^{54}$ Chandler, Scale and Scope, passim; Owens, "Inheritance", 21- 22; Colli \& al., "Long-Term", 842-843; Ojala \& al., "Competitive behaviour", 118-120; Nicholas, "Clogs to Clogs", 688-713.

${ }^{55}$ Van Praag, "Business survival", 1-17; Casson, "Entrepreneurship", 30 - 54.

${ }^{56}$ Kellermanns \& Eddleston, "Corporate entrepreneurship", 809-830 - See also Kreiser \& al, "Historical", 100 114.

${ }^{57}$ Business historical analysis in: Ojala \& al., "Competitive behaviour", 118-137. - See also Le Breton-Miller \& Miller, "Why Do Some", 731-746; Eddleston et al., "Governance and trust", 1043-1056; Lumpkin \& Brigham, "Long-Term", 1149-1169.

${ }^{58}$ Le Breton-Miller and Miller, "Why Do Some", 731-746

${ }^{59}$ March, "Exploration and Exploitation", 71 - 87; O’Reilly \& Tushman, “Ambidexterity", 185 - 206.

${ }^{60}$ Napolitano et al., 'Moving forward', 19-21.

${ }^{61}$ Burgelman \& Grove, "Let chaos reign", 965-979.

${ }^{62}$ Fridenson, "Business Failure", pp. 562-582.

${ }^{63}$ Kieser, "Why Organisation", 608-620; Rowlinson, "Business History", 1-23; Üsdiken \& Kieser, "Introduction", 321-330; Clark \& Rowlinson, "Treatment of History", 331-352; Kipping \& Üsdiken, "Business History", 96-119.

${ }^{64}$ Teece \& al., "Dynamic Capabilities", 509-533.

${ }^{65}$ Kay, "Sometimes". Levitt, "Marketing myopia", 24-47.

${ }^{66}$ Freeman \& al., "Stakeholder Theory", 364-369. 